NASA/TM-2005-213980

\title{
An Overview and Status of NASA's Radioisotope Power Conversion Technology NRA
}

David J. Anderson, Wayne A. Wong, and Karen L. Tuttle

Glenn Research Center, Cleveland, Ohio 
Since its founding, NASA has been dedicated to the advancement of aeronautics and space science. The NASA Scientific and Technical Information (STI) Program Office plays a key part in helping NASA maintain this important role.

The NASA STI Program Office is operated by Langley Research Center, the Lead Center for NASA's scientific and technical information. The NASA STI Program Office provides access to the NASA STI Database, the largest collection of aeronautical and space science STI in the world. The Program Office is also NASA's institutional mechanism for disseminating the results of its research and development activities. These results are published by NASA in the NASA STI Report Series, which includes the following report types:

- $\quad$ TECHNICAL PUBLICATION. Reports of completed research or a major significant phase of research that present the results of NASA programs and include extensive data or theoretical analysis. Includes compilations of significant scientific and technical data and information deemed to be of continuing reference value. NASA's counterpart of peerreviewed formal professional papers but has less stringent limitations on manuscript length and extent of graphic presentations.

- TECHNICAL MEMORANDUM. Scientific and technical findings that are preliminary or of specialized interest, e.g., quick release reports, working papers, and bibliographies that contain minimal annotation. Does not contain extensive analysis.

- CONTRACTOR REPORT. Scientific and technical findings by NASA-sponsored contractors and grantees.
- CONFERENCE PUBLICATION. Collected papers from scientific and technical conferences, symposia, seminars, or other meetings sponsored or cosponsored by NASA.

- SPECIAL PUBLICATION. Scientific, technical, or historical information from NASA programs, projects, and missions, often concerned with subjects having substantial public interest.

- TECHNICAL TRANSLATION. Englishlanguage translations of foreign scientific and technical material pertinent to NASA's mission.

Specialized services that complement the STI Program Office's diverse offerings include creating custom thesauri, building customized databases, organizing and publishing research results ... even providing videos.

For more information about the NASA STI Program Office, see the following:

- Access the NASA STI Program Home Page at http://www.sti.nasa.gov

- E-mail your question via the Internet to help@sti.nasa.gov

- Fax your question to the NASA Access Help Desk at 301-621-0134

- Telephone the NASA Access Help Desk at 301-621-0390

- Write to:

NASA Access Help Desk

NASA Center for AeroSpace Information 7121 Standard Drive

Hanover, MD 21076 
NASA/TM-2005-213980

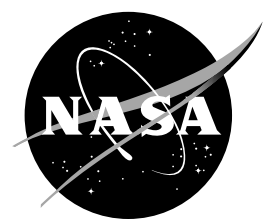

\section{An Overview and Status of NASA's Radioisotope Power Conversion Technology NRA}

David J. Anderson, Wayne A. Wong, and Karen L. Tuttle Glenn Research Center, Cleveland, Ohio

Prepared for the

Third International Energy Conversion Engineering Conference sponsored by the American Institute of Aeronautics and Astronautics San Francisco, California, August 15-18, 2005

National Aeronautics and

Space Administration

Glenn Research Center 


\section{Acknowledgments}

The results and findings presented here are based on work funded by the National Aeronautics and Space Administration (NASA) under the Radioisotope Power Conversion Technology NASA Research Announcement NRA 02-OSS-01 issued through the Science Mission Directorate. The authors would also like to acknowledge the hard work of the respective contractor teams, and the NASA contract and technical monitors and appreciate their help in contributing information for, or reviewing this paper.

This report contains preliminary

findings, subject to revision as analysis proceeds.

Available from

NASA Center for Aerospace Information 7121 Standard Drive

Hanover, MD 21076
National Technical Information Service 5285 Port Royal Road Springfield, VA 22100 


\title{
An Overview and Status of NASA's Radioisotope Power Conversion Technology NRA
}

\author{
David J. Anderson, Wayne A. Wong, and Karen L. Tuttle \\ National Aeronautics and Space Administration \\ Glenn Research Center \\ Cleveland, Ohio 44135
}

\begin{abstract}
NASA's Advanced Radioisotope Power Systems (RPS) development program is developing next generation radioisotope power conversion technologies that will enable future missions that have requirements that can not be met by either photovoltaic systems or by current Radioisotope Power System (RPS) technology. The Advanced Power Conversion Research and Technology project of the Advanced RPS development program is funding research and technology activities through the NASA Research Announcement (NRA) 02-OSS-01, "Research Opportunities in Space Science 2002" entitled "Radioisotope Power Conversion Technology" (RPCT), 13 August 2002. The objective of the RPCT NRA is to advance the development of radioisotope power conversion technologies to provide significant improvements over the state-of-practice General Purpose Heat Source/Radioisotope Thermoelectric Generator by providing significantly higher efficiency to reduce the number of radioisotope fuel modules, and increase specific power (watts/kilogram). Other Advanced RPS goals include safety, long-life, reliability, scalability, multi-mission capability, resistance to radiation, and minimal interference with the scientific payload. These advances would enable a factor of 2 to 4 decrease in the amount of fuel required to generate electrical power. The RPCT NRA selected advanced RPS power conversion technology research and development proposals in the following three areas: innovative RPS power conversion research, RPS power conversion technology development in a nominal $100 \mathrm{~W}_{\mathrm{e}}$ scale; and, milliwatt/multi-watt RPS (mWRPS) power conversion research. Ten RPCT NRA contracts were awarded in 2003 in the areas of Brayton, Stirling, thermoelectric (TE), and thermophotovoltaic (TPV) power conversion technologies. This paper will provide an overview of the RPCT NRA, and a brief summary of accomplishments over the first 18 months but focusing on advancements made over the last 6 months.
\end{abstract}

\section{Introduction}

Radioisotope fueled power systems have a long history of successful National Aeronautics and Space Administration (NASA) space flight missions. Radioisotope Power Systems (RPS) are capable of producing electricity for decades under the harsh conditions of deep space. An RPS converts the heat generated from the natural decay of radioisotope material into useful electrical power. They are most attractive in deep space applications where the solar flux is too low, or for extended planetary applications such as that on Mars where the day/night cycle, settling of dust, and long-life requirements limit the usefulness of photovoltaics. ${ }^{1}$

NASA has used RPS reliably in space exploration for more than 35 years. The current state-of-practice RPS used on NASA missions is the Radioisotope Thermoelectric Generator (RTG), which incorporates DOE's General Purpose Heat Source (GPHS) modules. The GPHS-RTG, which uses Silicon-Germanium thermoelectric (TE) power conversion, was utilized on NASA missions Galileo, Ulysses, and Cassini. While the GPHS-RTG is a proven, reliable design, it has a relatively low power conversion efficiency of about 7\%, a Beginning-of-Mission (BOM) system specific power of about $5 \mathrm{~W} / \mathrm{kg}$, and is limited to vacuum environment applications only. ${ }^{2}$

Current RPS development efforts, which include the Multi-Mission Radioisotope Thermoelectric Generator (MMRTG) and the Stirling Radioisotope Generator (SRG), are aimed at re-establishing the production of an RPS since the last of the already produced RTGs will be utilized on nearer term missions. The MMRTG and SRG efforts are also focusing on improving performance, and allowing multi-mission applications, while maintaining reliability for long life. A summary of the MMRTG and SRG programs can be found in Ref. 3.

NASA anticipates future mission requirements that go beyond the capabilities of MMRTG and SRG requiring advanced RPS that offer better performance and higher specific power. NASA has identified a number of potential missions that would require more advanced radioisotope generators. Future potential planetary missions require RPS that can work reliably for long periods of time in both vacuum and planetary atmospheres. As power requirements 
vary from mission to mission, future potential missions would also require a technology that can be scalable from a few watts to a few hundred watts. NASA and DOE are developing advanced, high-efficiency radioisotope power convertors to enable the next ambitious steps in exploration of our solar system using safe and cost effective spacecraft. ${ }^{4}$

\section{Radioisotope Power Conversion Technology Objectives}

The objective of the NASA RPS development program is to develop power conversion technologies that will enable future missions that have requirements that cannot be met by either photovoltaic systems or by current RPS. Advanced RPS performance goals include improvement over the state-of-practice GPHS-RTG including significantly higher efficiency to reduce the number of GPHS modules and higher specific power. Other general advanced RPS goals include safety, long-life (14 years, with well understood degradation), reliability, scalability, multi-mission capability (vacuum and atmosphere), resistance to radiation (from the GPHS or potential mission environments), and minimal interference with the scientific payload.

To that end, the NASA Research Announcement (NRA) 02-OSS-01, "Research Opportunities in Space Science 2002" entitled "Radioisotope Power Conversion Technology" (RPCT), 13 August 2002 was initiated to advance the development of radioisotope power conversion technologies to provide higher efficiencies and specific powers than existing systems. ${ }^{4}$ The RPCT NRA contracts are investigating several radioisotope power conversion technologies for space applications that involve both more efficient conversion of heat into electricity and reduced system mass. The higher efficiencies of these new technologies mean that future spacecraft may require less fuel than current RTGs typically use. Advances made under the RPCT NRA would decrease the amount of radioisotope fuel required by a factor of two to four and reduce the waste heat generated to produce electrical power, and thus could result in more cost effective science missions for NASA. This makes the development of these new space power technologies highly attractive.

\section{RPCT Contract Organization}

The RPCT NRA resulted in advanced RPS power conversion technology research and development efforts in the following three areas: ${ }^{2,4}$

1) Research on 100 We class RPS power conversion technologies

2) Development of $100 \mathrm{We}$ class RPS power conversion technologies

3) Research on Milliwatt/multi-watt RPS (mWRPS) power conversion

Ten RPCT NRA contracts were initially awarded in the areas of Brayton, Stirling, thermoelectric (TE), and thermophotovoltaic (TPV) power conversion technologies. The initial selections include five larger development contracts using more mature technology (Technology Readiness Level (TRL) 3 to 5) and five smaller research contracts using less mature technology (TRL 1 to 3). Ref. 2 and 4 provide more details on the RPCT NRA, a summary of how an RPS works, a brief description of the RPCT NRA research areas, and a brief summary of the four power conversion technologies being pursued.

Each RPCT NRA contract has a period of performance of up to three years, divided into three one-year phases, with options to continue the following phase after the conclusion of the prior phase. Phase I started with ten contracts in the summer/fall of calendar year 2003. In the July/August 2004 timeframe, an annual review was conducted of all ten Phase I RPCT NRA contracts. A decision was made to continue seven of the ten contracts into Phase II, and to let an eighth contract complete a major Phase I module fabrication and test task. Phase II started in the November 2004 to January 2005 timeframe. However, due to a severe budget reduction in January of 2005, four of the Phase II contracts had to be stopped and only three of the Phase II contracts ultimately continued. Table 1 shows the changes to the Phase-to-Phase RPCT NRA contract portfolio. 
TABLE 1.-PHASE-TO-PHASE SUMMARY OF FUNDED RPCT NRA EFFORTS

\begin{tabular}{|l|c|c||c|c||c|c|}
\hline & $\begin{array}{c}\text { Phase I } \\
\text { Completed }\end{array}$ & $\begin{array}{c}\text { Phase I } \\
\text { Completed }\end{array}$ & $\begin{array}{c}\text { Phase II } \\
\text { Initiated }\end{array}$ & $\begin{array}{c}\text { Phase II } \\
\text { Initiated }\end{array}$ & $\begin{array}{c}\text { Phase II } \\
\text { Continued }\end{array}$ & $\begin{array}{c}\text { Phase II } \\
\text { Continued }\end{array}$ \\
\hline & $\begin{array}{c}\text { Research } \\
\text { TRL 1-3 }\end{array}$ & $\begin{array}{c}\text { Development } \\
\text { TRL 3-5 }\end{array}$ & $\begin{array}{c}\text { Research } \\
\text { TRL 1-3 }\end{array}$ & $\begin{array}{c}\text { Development } \\
\text { TRL 3-5 }\end{array}$ & $\begin{array}{c}\text { Research } \\
\text { TRL 1-3 }\end{array}$ & $\begin{array}{c}\text { Development } \\
\text { TRL 3-5 }\end{array}$ \\
\hline TE mW & $\mathbf{2}$ & $\mathbf{0}$ & $\mathbf{1}$ & $\mathbf{0}$ & $\mathbf{0}$ & $\mathbf{0}$ \\
\hline TE & $\mathbf{1}$ & $\mathbf{1}$ & $\mathbf{1}$ & $\mathbf{0}$ & $\mathbf{1}$ & $\mathbf{0}$ \\
\hline TPV & $\mathbf{1}$ & $\mathbf{2}$ & $\mathbf{0}$ & $\mathbf{2}$ & $\mathbf{0}$ & $\mathbf{0}$ \\
\hline Stirling & $\mathbf{1}$ & $\mathbf{1}$ & $\mathbf{1}$ & $\mathbf{1}$ & $\mathbf{1}$ & $\mathbf{1}$ \\
\hline Brayton & $\mathbf{0}$ & $\mathbf{1}$ & $\mathbf{0}$ & $\mathbf{1}$ & $\mathbf{0}$ & $\mathbf{0}$ \\
\hline
\end{tabular}

\section{Radioisotope Power Conversion Technology Goals and Accomplishments}

This paper will primarily focus on post RPCT Annual Review accomplishments that were presented in Ref. 2, and summarize other key accomplishments, if any, to date. Eight of the RPCT NRA contracts will be reported on in this paper. For each of the eight RPCT NRA contracts, a short description of the effort along with recent Phase II or on-going Phase I accomplishments will be summarized below.

Ref. 1 discussed the Phase I 6-month status, and Ref. 2 provides a summary of Phase I RPCT Annual Review accomplishments. Ref. 5, 7, and 9 to 14 are status papers prepared by the RPCT contractors covering Sunpower's Advanced Stirling Convertor development, Teledyne's TE research and development, MIT's TE research, Creare's Thermophotovoltaic technology development, Edtek's Thermophotovoltaic technology development, and Creare's Brayton development. The CSU's Stirling Regenerator research was reported on in Ref. 6.

\section{A. Stirling}

1. Advanced Stirling Convertor Development

The Sunpower led team consisting of Boeing Rocketdyne, Cleveland State University, University of Minnesota and consultants Penswick, Gedeon, Berchowitz, and Cairelli was awarded an NRA development contract to demonstrate an advanced Stirling converter with significant improvements over 1st-generation flight systems and to achieve converter efficiency of $>30 \%$ and a system specific power of $>8 \mathrm{~W} / \mathrm{kg}{ }^{3}{ }^{3}$. The key technologies from this effort are hydrostatic gas bearings, a moving magnet linear alternator, high temperature heater head materials and fabrication, high frequency operation, and a controller with active power factor correction. Currently, the expected efficiency of the Advanced Stirling Convertor (ASC) is $\sim 40 \%$ (AC power out/heat in), and the convertor specific power is $90 \mathrm{~W}_{\mathrm{e}} / \mathrm{kg}$ resulting in a projected RPS specific power of $>8 \mathrm{~W} / \mathrm{kg}$. The ASC is designed with an advanced $850^{\circ} \mathrm{C}$ heater head using Mar-M-247. Sunpower's Frequency Test Bed (FTB) Stirling convertor was developed early in Phase I to allow frequency and advanced component investigations. The FTB performance has already surpassed project efficiency goals having demonstrated 36\% conversion efficiency (AC power out/heat in) at lower operating temperatures of $650^{\circ} \mathrm{C}$ hot end and $30^{\circ} \mathrm{C}$ cold end during Phase I. ${ }^{5} \mathrm{ASC}-1$ was designed in Phase I and four of these non-hermetically sealed units will be built in Phase II. Two of these units will operate in a dynamically opposed low vibration configuration. Launch vibration testing and component reliability testing is also planned for Phase II. Life testing of the ASC-1 will be initiated at the end of Phase II. Additional tasks include reliability studies and thermodynamic loss investigations. After the Phase I review, NASA directed Sunpower to include additional Phase II tasks that include a heat source thermal interface design; fabrication and testing of a foil regenerator; regenerator durability and reliability testing; additional heater head materials testing; EMI characterization and a vibration absorber investigation. In Phase III, four ASC-2s will be fabricated and tested. These low mass units will be hermetically-sealed and operate in dynamic opposition for testing and analysis. ${ }^{5}$ Sunpower's major accomplishments for Phase I and early Phase II are as follows:

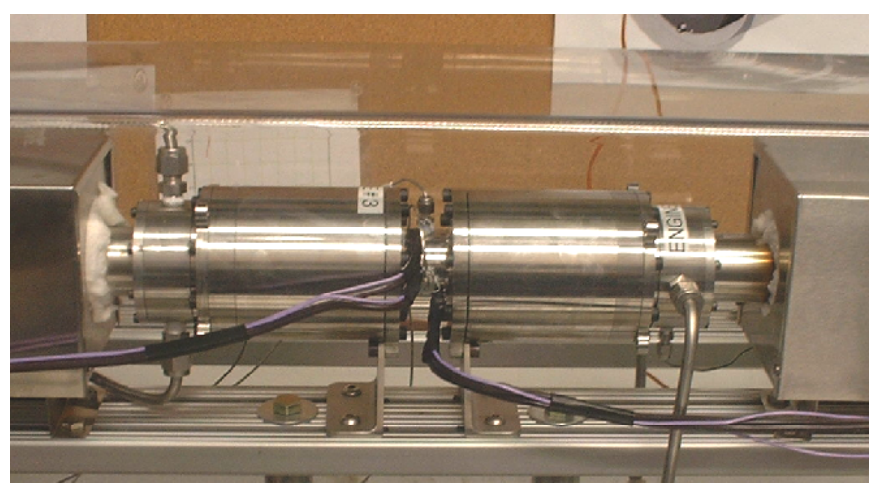

Figure 1.- Sunpower FTB convertors in operation. 
1) Completed the Phase I FTB convertor and demonstrated $36 \%$ efficiency at $\mathrm{T}_{\text {hot }}=650^{\circ} \mathrm{C}$ and $\mathrm{T}_{\text {cold }}=30^{\circ} \mathrm{C}$.

2) Completed design of the ASC-1 non-hermetically sealed units

3) Identified high temperature materials and joining techniques for ASC-1 units to allow for $850^{\circ} \mathrm{C}$ operation for improved performance.

4) Conducted a thorough reliability assessment to identify key elements that are now a part of a reliability test plan.

\section{Stirling Convertor Regenerator Microfabrication Research}

The Cleveland State University (CSU) led team consisting of the University of Minnesota, Gedeon Associates, Sunpower, and Stirling Technologies Company (now known as Infinia Corporation) was awarded an NRA research contract to develop an idealized Stirling regenerator that is built using microfabrication techniques which will exhibit improved thermal and flow performance and to characterize these performance enhancements in hardware demonstration. The Stirling Regenerator Microfabrication research effort focuses on reducing Stirling regenerator pressure drop losses and improving structural reliability through use of micro-fabrication processes, while maintaining or improving upon current regenerator thermal performance. Regenerator design is a key consideration in achieving high performance with both Stirling and the related thermoacoustic machines. This effort is addressing the significant performance improvements achieved through better understanding of regenerator flow fields and manifold effects. Projections indicate that performance improvements of 6 to $9 \%$ higher efficiency and power may be possible. ${ }^{6}$ CSU's major accomplishments for early Phase II are as follows:

1) Refined regenerator concept that is composed of stacks of microfabricated disks. Each disk has involute elements

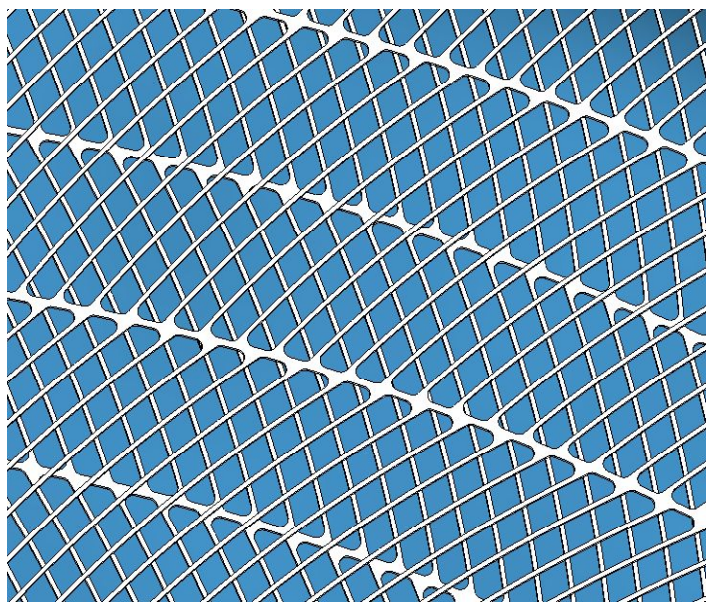

Figure 2.-CSU improved involute regenerator concept. slanted in the same direction, but are assembled with alternating involute disks in the opposite direction which enhances flow uniformity. Further, the position of the ring separator for the alternating disks are staggered to reduce the thermal conduction along the flow axis and allow radial flow mixing. Figure 2 shows the revised involute concept.

2) Fabrication of a nickel involute regenerator for the Sunpower oscillating flow rig is underway

3) Fabrication of elements for Large-Scale Mock-Up testing is proceeding

4) Conducting CFD simulations of Large-Scale Mock-Up hardware

\section{B. Thermoelectrics (TE)}

\section{Segmented BiTe/PbTe-BiTe/TAGS/PbSnTe Thermoelectric Generators Development}

An NRA development contract was awarded to Teledyne Energy Systems, Inc. (TESI) to improve performance and manufacturability of segmented BiTe with $\mathrm{PbTe}, \mathrm{PbSnTe}$ and TAGS unicouples in a power converter module and demonstrate $10-12 \%$ efficiency and $>5 \mathrm{~W} / \mathrm{kg}$ specific power. ${ }^{3}$ During Phase 1 TESI began the development of a thermoelectric (TE) radioisotope power converter with a TE efficiency goal of $10 \%$, a power output of $20 \mathrm{We}$ at $5 \mathrm{~V}$, and greater than $5 \mathrm{~W} / \mathrm{kg}$ system specific power. TESI produced a baseline $20 \mathrm{~W}_{\mathrm{e}}$ compact module sized to match a single General Purpose Heat Source (GPHS) module. The baseline module design is based on the TESI terrestrial-based Sentinel commercial generator design and uses state-of-practice BiTe segmented with $\mathrm{PbTe}, \mathrm{PbSnTe}$ and TAGS TE unicouples. TESI also conducted TE material studies to improve performance as well as developed an

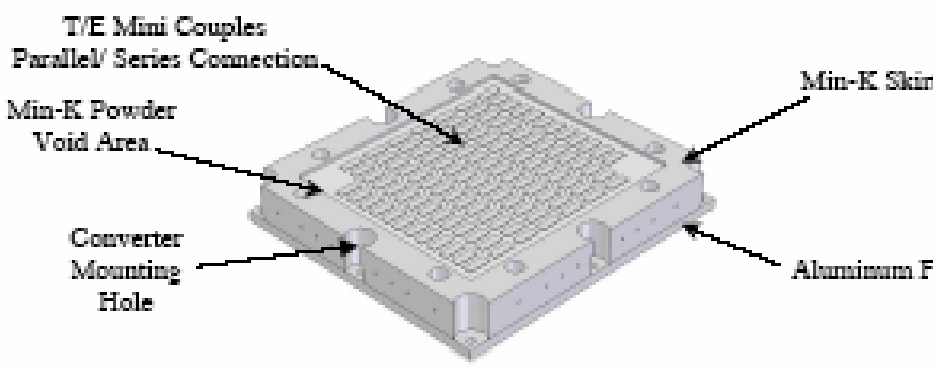

Figure 3.-TESI $20 \mathrm{~W}$ baseline module concept. 
improved segmented TE couple model to evaluate material composition and segment sizing for a given temperature. Phase II and III goals were to improve the baseline converter's design and efficiency. However, as a result of a down-select process at the end of Phase I, NASA did not exercise the Phase II option. TESI is currently testing the baseline Phase I compact module to evaluate its performance under a no-cost extension of Phase I. ${ }^{7}$ TESI's major accomplishments to date for are as follows:

1) Developed a system concept based to meet $20 \mathrm{~W}, 5 \mathrm{~V}$ power goal utilizing one GPHS module and improved to $24 \mathrm{~W}$ through optimization of sizing and temperatures

2) Designed and fabricated the baseline TE compact module with mini-couples

3) TAGS sublimation test effort started

4) Mechanically alloyed various common thermoelectric materials

5) Developed a viable co-hot pressing process

6) Developed successful TAGS-80 and TAGS-85 compositional changes

2. Si-Ge Nanocomposites for Radioisotope Power Conversion Research

Massachusetts Institute of Technology (MIT) has teamed with Boston College (BC) and the Jet Propulsion Laboratory (JPL) on a thermoelectric material NRA research contract to improve the figure-of-merit (ZT) of bulk SiGe by investigating the development of bulk nanocomposite SiGe. This nanostructure technology promises to increase the material's performance by increasing the Seebeck coefficient and reducing the thermal conductivity without affecting the electrical conductivity. As a result, there is a net gain in the ZT. The goal is to demonstrate ZT of $\sim 2$ at $900 \mathrm{~K}$ with efficiency of $12-14 \%$. In addition, once perfected, synthesizing bulk nanocomposites is a large-scale manufacturing process that is needed when producing large numbers of thermoelectric couples. Specific areas of this research activity include nanostructure synthesis, structural characterization, thermoelectric properties characterization and modeling of the nanocomposites. Accomplishments for Phase I are listed below. Phase II and III activities will continue to improve the quality of the $\mathrm{Si}$ and Ge nanostructures for higher performance and continue with property measurements, characterization, and modeling. ${ }^{8}$ The MIT/BC/JPL team accomplishments for the Phase I and Phase II effort included:

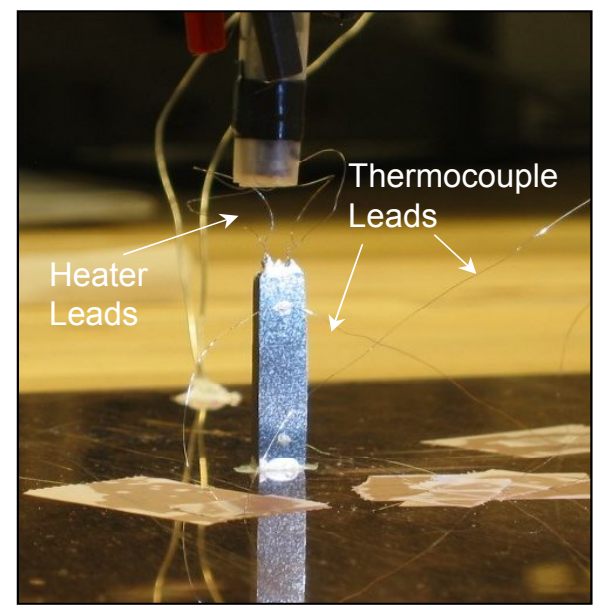

Figure 4.-MIT TE sample and measurement setup.

1) Synthesis of high quality $\mathrm{Si}$ and Ge nanowires

2) Synthesis of $\mathrm{Si}$ and $\mathrm{Ge}$ nanoparticles

3) Synthesis of SiGe nanocomposites by induction furnace method and Plasma Pressure Compaction

4) Developed a new heat treatment for the SiGe alloy that showed a 50\% increase of ZT at room temperature

5) Phonon Transport Modeling of two dimensional SiGe nanocomposites

6) Modeling of material properties for enhanced materials design

\section{Milli-Watt Thermoelectrics (mW TE)}

\section{Advanced Superlattice BiTe-PbTe/TAGS Milliwatt Radioisotope Power Systems Research}

An NRA research contract was awarded to Teledyne Energy Systems, Inc. (TESI) and Research Triangle Institute (RTI) to develop a cascaded PbTe/TAGS-Superlattice BiTe TE module for milliwatt applications and demonstrate module efficiency of $\geq 8 \%$ with power outputs of 50 to several $100 \mathrm{~mW}$. ${ }^{3}$ During this research effort, TESI and RTI set about to develop a high efficiency, two-stage cascaded thermoelectric converter for use in future milliwatt radioisotope power source (mWRPS) applications using one or more radioisotope heater units (RHU) as the heat source. The hot stage device, developed by TESI, is a miniature conventional T/E converter composed of over $80 \mathrm{~T} / \mathrm{E}$ couples, which are glass bonded into a monolithic multicouple block. The hot stage device uses Teledyne's segmented $\mathrm{PbTe} / \mathrm{TAGS} / \mathrm{PbSnTe} \mathrm{T} / \mathrm{E}$ device technology and is designed to produce $2 / 3$ of the total power output. The cold stage device, developed by RTI, is a high efficiency superlattice BiTe based device that will produce approximately $1 / 3$ of the total power output. The electrical compatibility between the high voltage-low current power output mode of the hot stage device operating with the low voltage-high current power output mode of the superlattice cold stage device is a technical challenge. While investigating a solution for this problem TESI designed a fully segmented $\mathrm{PbTe} / \mathrm{BiTe}-\mathrm{PbSnTe} / \mathrm{TAGS} / \mathrm{BiTe} \mathrm{TE}$ module. This TE module would meet the programs 
technical objectives, operate between $720 \mathrm{~K}-300 \mathrm{~K}$ and produce end of mission power of about $55 \mathrm{~mW}$ using a single RHU with nominal 1 thermal watt heat output rate. The thermoelectric efficiency is expected to be $10.3 \%$ with a system efficiency of $8.8 \%$. This module would not be used in conjunction with a superlattice based RTI device. RTI completed the construction of 4 high element aspect ratio Superlattice devices to be tested independently. Figure 5 shows a cross-section of improved glass bonds demonstrating bond line uniformity. ${ }^{9}$ This contract was terminated after the start of Phase II due to NASA funding cuts. TESI's major accomplishments for Phase I and early Phase II are as follows:

1) Developed several material and fabricating process improvement for the quantity production of very small TE material slices into multicouple arrays

2) Developed an innovative technique to assure full separation and electrical isolation of TE material slices after glass bonding

3) Developed a step-grading process to form a thicker superlattice BiTe film allowing increased L/A ratios

4) Found alternative materials to lower parasitic losses in the superlattice device

5) Fabricated several glass-bonded linear array multicouple hot stage devices as well as a high performance superlattice unicouple and multicouple with results that exceed bulk BiTe material couple and module performance by more than $50 \%$.

\section{Thermophotovoltaic (TPV)}

\section{Thermophotovoltaic Power Conversion Technology For Radioisotope Power Systems Development}

The Creare Inc./EMCORE Corp./ NASA GRC/Polytechnic University/Oak Ridge National Laboratory team was awarded an NRA development contract to demonstrate a selective emitter-based TPV power generator with a simulated radioisotope thermal source and a target $15-20 \%$ converter efficiency and $\sim 15 \mathrm{~W} / \mathrm{kg}$ specific power. ${ }^{3}$ This TPV development effort involved the development of an advanced TPV concept that includes high temperature selective emitters, filters and advanced lattice-mismatched InGaAs PV cells. Creare's baseline converter design included a 4x4 InGaAs array for high power output, a tandem plasma/dielectric filter for spectral control to maximize conversion efficiency and tungsten emitters to achieve the heat balance necessary to meet the power input and the temperature constraints of the RPS. Creare expected to demonstrate a system conversion efficiency of $15-20 \%$, a specific power of $10-15 \mathrm{~W}_{\mathrm{e}} / \mathrm{kg}$, and a TRL of 5. The TPV array developed and tested under Phase I has an efficiency of $19 \%$ and more than $50 \mathrm{~W}_{\mathrm{e}}$ for a prototypical array size of about $100 \mathrm{~cm}^{2}$ with an emitter temperature of $1350 \mathrm{~K}$ and a heat rejection temperature of $300 \mathrm{~K}$. Creare began work on a detailed design of a test article that would improve upon the baseline converter when NASA funding cuts required the termination of this contract. ${ }^{10,11}$ Creare's major accomplishments for Phase I and early Phase II are as follows:

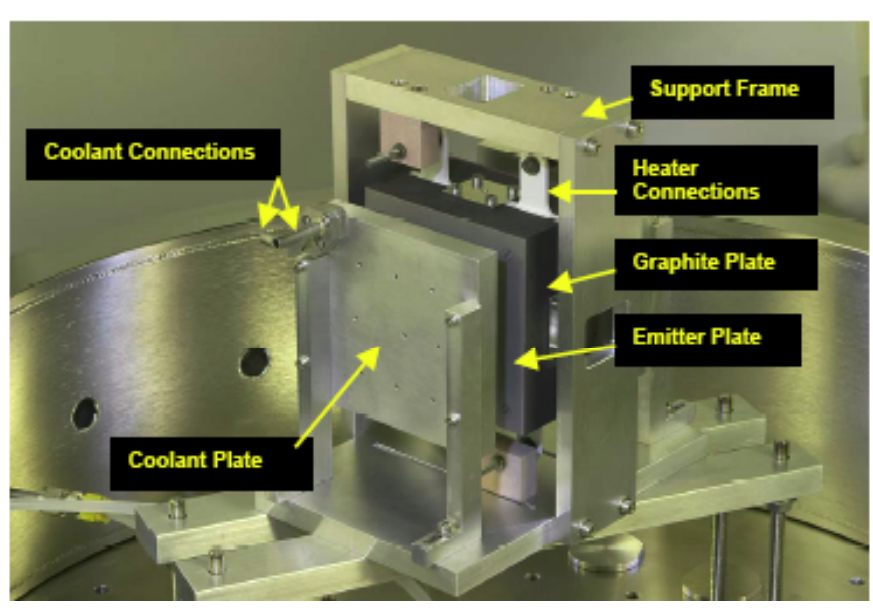

Figure 6.-Creare TPV test article without insulation.

1) Demonstrated conversion efficiency of $19 \%$ with a PV cell array in a test configuration that lacked only a housing and DC-DC power regulation

2) Developed a detailed performance model that includes radiation, conduction, convection heat transfer and PV cell electrical performance that compares well with experimental data.

3) InGaAs PV cells were consistently fabricated with high performance.

4) Prepared an ultra-high vacuum facility to perform materials evaporation and deposition tests for operation 
5) Determined that the GPHS heat source neutron irradiation will not affect the optical characteristics of the PV cells and tandem filters over the 14-year mission. Also determined that the PV cell output power would degrade by a factor of .8 due to the neutron irradiation over the 14-year mission.

2) Thermophotovoltaic Radioisotope Power Conversion Technology Development

The EDTEK Inc./University of Houston was awarded an NRA development contract to demonstrate a TPV power generator employing improvements in the GaSb PV cell, IR filter housing and thermal isolation of PV array and achieve efficiency and specific power of $\sim 30 \%$ and $>8 \mathrm{~W} / \mathrm{kg} .{ }^{3}$ This TPV RPCT development effort involves development of a TPV concept that could provide a 3 to 4 -fold improvement in system efficiency over current thermoelectric-based radioisotope generators. The key technological innovations are a novel integrated cell front contact and concentrator scheme, a unique tuned Frequency Selective Surface (FSS) filter array, a non-contaminating emitter, improvements in $\mathrm{GaSb}$ photovoltaic cell technology, and a unique scheme for thermal management that will allow a reduction in total system mass by about a factor of 3 . Performance goal is to achieve $17-23 \%$ converter efficiency, which is estimated to provide an RPS specific power of $>8 \mathrm{~W} / \mathrm{kg} .{ }^{12,13}$ This contract was terminated after the start of Phase II due to NASA funding cuts. The Edtek/U. Houston team accomplishments for the Phase I and early Phase II effort included:

1) An efficiency of $20 \%$ was demonstrated in

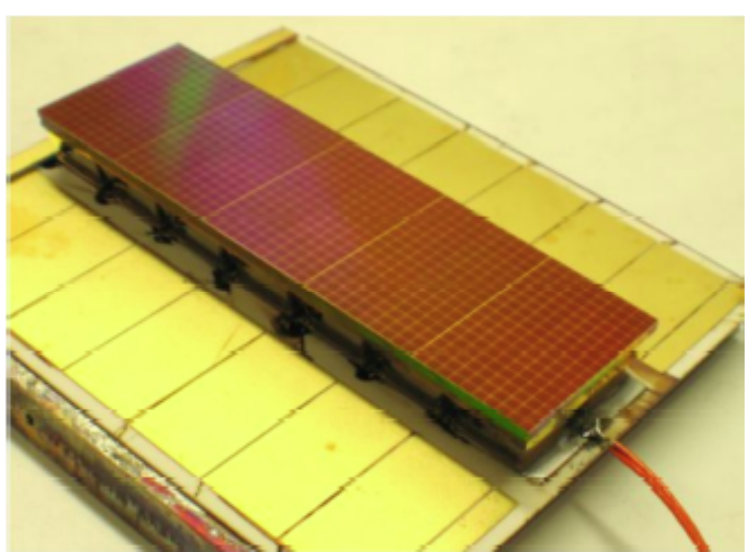

Figure 7.-Edtek TPV cell and prism array test apparatus with IR Bandpass filter in place. Edtek's TPV cell and prism array shown in Figure 7 . Three of these arrays make up a $4 \times 4$ in. unit.

2) Advanced development work was performed on 1) an integrated filter TPV cell contact and 2) advanced filter modeling and fabrication technologies for designing and optimizing single layer filter performances and to design, evaluate and fabricate multilayer filters.

3) Fabricated large-area Aperture Array Lithography (AAL) masks, by prototyping five unique filter designs, and by developing a three-dimensional model that accurately predicts the behavior of the fabricated IR filters.

4) Developed a concept to thermally isolate the filter and housing from the prism/cell convertor assembly. The filter and housing can operate at higher temperatures, and through the use of a split radiator, can reject waste heat using a smaller radiator (potentially by a factor of 2 ).

\section{E. Brayton}

1) Advanced Turbo-Brayton Power System for Radioisotope Power Systems development

The Creare Inc. led team composed of Ball Aerospace, Boeing Rocketdyne, and Jackson \& Tull was awarded an NRA development contract to develop a Turbo-Brayton Power System (TBPS) and demonstrate operation of a low mass mini turbo-Brayton converter that would achieve an efficiency of $25-36 \%$ and specific power of $9-13 \mathrm{~W} / \mathrm{kg}^{3}$ Key to this effort is application of micromachining and fabrication techniques to build a very small, compact turbine-alternator. During the first year the design, analysis and demonstrations efforts were geared towards addressing the key technical challenges of extending Creare's turboBrayton cryocooler technologies to high temperature operation in an RPS. To address the key challenges, the first year of this effort was focused on proof-of-concept demonstrations and the thermo-mechanical design of the convertor. The TBPS is to be integrated with two GPHS modules, and is predicted to produce $104 \mathrm{We}$ of 28 VDC output power, with a convertor

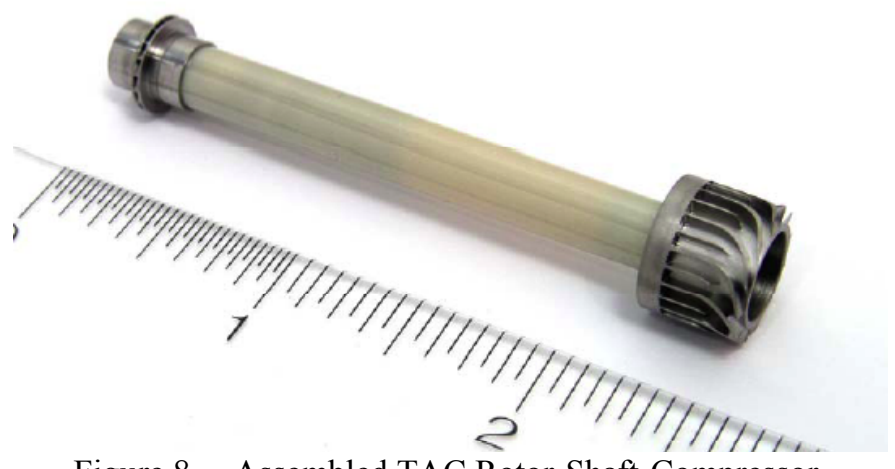

Figure 8.-Assembled TAC Rotor-Shaft-Compressor. 
efficiency of $\sim 23 \%$ and a system efficiency $\sim 21 \%$ with a turbine inlet temperature of $1050 \mathrm{~K}$ (1100K hot side interface), and a compressor inlet temperature of 332K. Figure 8 includes a photograph of a titanium alloy compressor, zirconia shaft, and a niobium alloy turbine fabricated using Creare's precision fabrication capability. ${ }^{14}$ This contract was terminated after the start of Phase II due to NASA funding cuts. The key Phase I accomplishments for the Creare Brayton effort included:

1) Completed material and fabrication evaluations, and the demonstration of a high temperature rotor, lightweight recuperator, and power conversion electronics

2) Completed design, fabrication, and assembly of a Turbo-Alternator-Compressor (TAC), temperature cycled the unit to demonstrate mechanical integrity, spin tested the prototype TAC to demonstrate its dynamic behavior, and completed 200 start/stop cycles without noticeable degradation

3) Completed a conceptual design of a Turbo-Brayton convertor

4) Identified an alternate conceptual convertor design with a higher level of component integration to be a more flight-like package to reduce mass and improve efficiency

\section{Conclusion}

This paper described the Radioisotope Power Conversion Technology NASA Research Announcement, and its focus to advance the development of radioisotope power conversion technologies to provide higher efficiencies and specific powers than existing systems. Results from eight of RPCT NRA contracts in the areas of Brayton, Stirling, thermoelectric (TE), and thermophotovoltaic (TPV) power conversion technology efforts have been summarized. The advances from these RPCT NRA efforts will enable more cost effective science missions for NASA.

\section{References}

${ }^{1}$ Wong, W.A., “Advanced Radioisotope Power Conversion Technology Research \& Development," AIAA-2004-5515, Proceedings of the 2nd International Energy Conversion Engineering Conference (IECEC 2004), Providence, RI, August 16-19, 2004.

${ }^{2}$ Anderson, D.J., "NASA Radioisotope Power Conversion Technology NRA Overview," Space Technology and Applications International Forum (STAIF 2005), Albuquerque, NM, February 14-17, 2005.

${ }^{3}$ Schmidt, G.R., Wiley, R.L., Richardson, R.L, "NASA's Program for Radioisotope Power System Research and Development," Space Technology and Applications International Forum (STAIF 2005), Albuquerque, NM, February 14-17, 2005.

${ }^{4}$ NASA, Amendment to NASA Research Announcement NRA 02-OSS-01-RPCT, "Research Opportunities in Space Science 2002 entitled Radioisotope Power Conversion Technology," (2002) http://research.hq.nasa.gov/code_s/nra/current/NRA-05-OSS01-rpct/index.html, accessed November 2004.

${ }^{5}$ Wood, J.G., Carroll, C., Penswick, L.B., “Advanced 80 We Stirling Convertor Development Progress,” Space Technology and Applications International Forum (STAIF 2005), Albuquerque, NM, February 14-17, 2005.

${ }^{6}$ Ibrahim, M. B., Veluri, S., Simon, T., Gedeon, D., "CFD Modeling of Surface Roughness in Laminar Flow," AIAA-20045585, Proceedings of the 2nd International Energy Conversion Engineering Conference (IECEC 2004), Providence, RI, August 16-19, 2004.

${ }^{7}$ Flanders, L.A., Drinker, R.W., Heshmatpour, B., Moul, D.S., Fleurial, J.-P., Tuttle, K.L., "Improvements in Materials and Processes for Segmented BiTe/PbTe- BiTe/TAGS/PbSnTe Based Thermoelectric Generators," Space Technology and Applications International Forum (STAIF 2005), Albuquerque, NM, February 14-17, 2005.

${ }^{8}$ Dresselhaus, M.S., Chen, G., Ren, Z.F., Fleurial, J.-P., Gogna, P., "Si-Ge Nanocomposites for Radioisotope Power Conversion," presented at Direct Energy Review and Workshop, Coronado, CA, December 13-15, 2004.

${ }^{9}$ Drinker, R.W., Heshmatpour, B., Reddy, A., Snyder, G.J., Tuttle, K.L., “Advanced Superlattice BiTe-PbTe/TAGS Milliwatt Radioisotope Power System," Space Technology and Applications International Forum (STAIF 2005), Albuquerque, NM, February 14-17, 2005.

${ }^{10}$ Crowley, C.J., Elkouh, N.A., Murray, S.L., Chubb, D.L., "Thermophotovoltaic Converter Performance for Radioisotope Power Systems," Space Technology and Applications International Forum (STAIF 2005), Albuquerque, NM, February 14-17, 2005.

${ }^{11}$ Newman, F.D., Murray, S.L., Endicter, S.P., Aiken, D.J., Girard, G.R., Turner, M., Sharps, P.R., "Development of Thermophotovoltaic Devices Optimized for High Temperature Operation," Space Technology and Applications International Forum (STAIF 2005), Albuquerque, NM, February 14-17, 2005.

${ }^{12}$ Horne, W.E., Morgan, M.D., Horne, W.P., Sundaram, V.S., "Frequency Selective Surface Bandpass Filters Applied to Radioisotope Thermophotovoltaic," Space Technology and Applications International Forum (STAIF 2005), Albuquerque, NM, February 14-17, 2005.

${ }^{13}$ Xu, B., Sundaram, V.S., Morgan, M.D., Horne W.E., "Integrated Bandpass Filter Contacts for GaSb Thermophotovoltaic Cells," Space Technology and Applications International Forum (STAIF 2005), Albuquerque, NM, February 14-17, 2005.

${ }^{14}$ Zagarola, M.V., Izenson, M.G., Breedlove, J.J., O'Connor, G.M., Ketchum, A.C., Jetley, R.L., Simons, J.K., "An Advanced Turbo-Brayton Convertor for Radioisotope Power Systems," Space Technology and Applications International Forum (STAIF 2005), Albuquerque, NM, February 14-17, 2005. 
Public reporting burden for this collection of information is estimated to average 1 hour per response, including the time for reviewing instructions, searching existing data sources, gathering and maintaining the data needed, and completing and reviewing the collection of information. Send comments regarding this burden estimate or any other aspect of this collection of information, including suggestions for reducing this burden, to Washington Headquarters Services, Directorate for Information Operations and Reports, 1215 Jefferson Davis Highway, Suite 1204, Arlington, VA 22202-4302, and to the Office of Management and Budget, Paperwork Reduction Project (0704-0188), Washington, DC 20503.

\begin{tabular}{|l|l|l}
\hline 1. AGENCY USE ONLY (Leave blank) & $\begin{array}{c}\text { 2. REPORT DATE } \\
\text { November } 2005\end{array}$ & $\begin{array}{r}\text { 3. REPORT TYPE AND DATES COVERED } \\
\text { Technical Memorandum }\end{array}$ \\
\hline
\end{tabular}

\section{TITLE AND SUBTITLE} 5. FUNDING NUMBERS

An Overview and Status of NASA's Radioisotope Power Conversion Technology NRA

6. AUTHOR(S)

David J. Anderson, Wayne A. Wong, and Karen L. Tuttle

WBS-22-972-90-01

\section{PERFORMING ORGANIZATION NAME(S) AND ADDRESS(ES)}

National Aeronautics and Space Administration

John H. Glenn Research Center at Lewis Field

Cleveland, Ohio 44135-3191

8. PERFORMING ORGANIZATION REPORT NUMBER

E-15302

\section{SPONSORING/MONITORING AGENCY NAME(S) AND ADDRESS(ES)}

National Aeronautics and Space Administration

Washington, DC 20546-0001

10. SPONSORING/MONITORING AGENCY REPORT NUMBER

NASA TM-2005-213980

AIAA-2005-5713

\section{SUPPLEMENTARY NOTES}

Prepared for the Third International Energy Conversion Engineering Conference sponsored by the American Institute of Aeronautics and Astronautics, San Francisco, California, August 15-18, 2005. Responsible person, David J. Anderson, organization code PS, 216-433-8709.

\section{2a. DISTRIBUTION/AVAILABILITY STATEMENT}

12b. DISTRIBUTION CODE

Unclassified - Unlimited

Subject Categories: 20 and 44

Available electronically at http://gltrs.grc.nasa.gov

This publication is available from the NASA Center for AeroSpace Information, 301-621-0390.

\section{ABSTRACT (Maximum 200 words)}

NASA's Advanced Radioisotope Power Systems (RPS) development program is developing next generation radioisotope power conversion technologies that will enable future missions that have requirements that can not be met by either photovoltaic systems or by current Radioisotope Power System (RPS) technology. The Advanced Power Conversion Research and Technology project of the Advanced RPS development program is funding research and technology activities through the NASA Research Announcement (NRA) 02-OSS-01, "Research Opportunities in Space Science 2002" entitled "Radioisotope Power Conversion Technology" (RPCT), August 13, 2002. The objective of the RPCT NRA is to advance the development of radioisotope power conversion technologies to provide significant improvements over the state-of-practice General Purpose Heat Source/Radioisotope Thermoelectric Generator by providing significantly higher efficiency to reduce the number of radioisotope fuel modules, and increase specific power (watts/kilogram). Other Advanced RPS goals include safety, long-life, reliability, scalability, multi-mission capability, resistance to radiation, and minimal interference with the scientific payload. Ten RPCT NRA contracts were awarded in 2003 in the areas of Brayton, Stirling, thermoelectric (TE), and thermophotovoltaic (TPV) power conversion technologies. This paper will provide an overview of the RPCT NRA, and a brief summary of accomplishments over the first 18 months but focusing on advancements made over the last 6 months.

14. SUBJECT TERMS
Stirling cycle; Thermoelectric generators; Brayton cycle; Space missions; Thermophotovoltaic conversion; Energy conversion efficiency; Power convertors; Regenerators

17. SECURITY CLASSIFICATION OF REPORT

Unclassified

18. SECURITY CLASSIFICATION
OF THIS PAGE
Unclassified

19. SECURITY CLASSIFICATION OF ABSTRACT

Unclassified
15. NUMBER OF PAGES

14

16. PRICE CODE 20. LIMITATION OF ABSTRACT 

